DOI: $10.18276 /$ sip.2016.43/2-23

\title{
Adam Rudzewicz*
}

\section{POMIAR ZAUFANIA WEWNĘTRZNEGO W ORGANIZACJI}

\section{STRESZCZENIE}

Celem artykułu jest identyfikacja roli, jaką odgrywa zaufanie pracowników w funkcjonowaniu współczesnych organizacji, oraz próba bezpośredniego pomiaru zaufania wewnątrzorganizacyjnego. Zaufanie jest kluczem do motywowania ludzi, mobilizowania ich do pracy i osiągania wspólnych celów. Jeżeli ludzie nie ufają sobie, to nie osiągną sukcesu. Wiarygodność organizacji stanowi fundament lojalności pracowników. Zaufanie potrzebuje silnego przywództwa, zaangażowania, otwartej komunikacji i szczerych zachowań opartych na mocnych etycznych podstawach. Mimo niewątpliwie dużego znaczenia zaufania w organizacji, w praktyce jest to temat pomijany. Przeprowadzone badania w uczelni wyższej sugerują obecność negatywnych zjawisk. Pracownicy odczuwają niski stopień satysfakcji. Zaufanie pracowników do pracodawcy nie jest najmocniejszą stroną badanej uczelni.

Słowa kluczowe: zaufanie, organizacja, wizerunek, pracownicy

\section{Wprowadzenie}

Problematyka zaufania dotyka wielu przestrzeni badawczych, również zagadnień ekonomicznych i biznesowych. Zaufanie ma bardzo wymierną wartość pragmatyczną, a związane z nim lojalność i prawdomówność zwiększają wydajność systemu i pozwalają produkować więcej dóbr. Organizacja musi dbać o zaufanie klientów, kontrahentów, dostawców, wspólników i pracowników. Przedsiębiorstwo o nieskazitelnej reputacji jest atrakcyjne dla wysoko wykwalifikowanych pracowników oraz

\footnotetext{
* Uniwersytet Warmińsko-Mazurskiw Olsztynie, adres e-mail: adam.rudzewicz@uwm.edu.pl.
} 
potencjalnych inwestorów. Reputacja jest czynnikiem rozwojowym, zapewniającym ekonomiczne bezpieczeństwo i chroniącym w okresach kryzysowych (Andrzejczyk, 2015). Wizerunek oparty na zaufaniu potwierdza, że organizacja jest wiarygodna i kompetentna w tym, co robi.

Celem artykułu jest identyfikacja roli, jaką odgrywa zaufanie pracowników w funkcjonowaniu współczesnych organizacji. Ponadto dla lepszego zobrazowania problemu podjęto próbę bezpośredniego pomiaru zaufania wewnątrzorganizacyjnego na przykładzie wybranej uczelni wyższej.

\section{Zaufanie wewnątrzorganizacyjne}

Skuteczne zarządzanie organizacją nie jest możliwe bez wzajemnego zaufania pomiędzy pracownikami i ich przełożonymi. Pracodawca, któremu brakuje zdolności przywódczych wzbudzających zaufanie, może mieć trudności w prowadzeniu biznesu (Kiyosaki, Lechter 2006, s. 104). Z drugiej strony bez poczucia wiary w kompetencje i życzliwość pracowników kierownikom trudno będzie skorzystać z ich wiedzy i umiejętności (Levin, Cross, Abrams, Lesser, 2002, s. 8).

Zaufanie organizacyjne jest ogólną oceną tego, na ile dana organizacja troszczy się o pracowników lub inne istotne dla niej grupy, na ile jest szczera i otwarta, dająca szansę na identyfikację z nią. Zaufanie do organizacji jest bezpośrednio związane $\mathrm{z}$ wiarą, że organizacja funkcjonuje efektywnie, a jej pracownicy wykazują wysoki poziom zadowolenia z pracy. Wpływa to na skuteczność osiąganych przez firmę celów, zysków oraz gotowość pracowników do ponoszenia wysiłków na jej rzecz.

Zaufanie zależy od jakości pracy i autorytetu menedżera. Menedżerowie, którzy inspirują i budują zaufanie, mają lepsze wyniki w pracy, bardziej zaangażowanych pracowników, silniejsze sieci znajomości, stają przed większymi wyzwaniami i są częściej promowani, zajmują coraz wyższe stanowiska (Anderson, 2005, s. 392-404).

Z punktu widzenia menedżera zaufanie to wiara w siły i możliwości podwładnych, posiadane przez nich uzdolnienia, zamiłowania i możliwości skutecznego działania. Zaufanie wpływa na lojalność i wydajność pracowników, natomiast jego brak obniża produktywność i obroty firmy. Dlatego menedżerowie w budowaniu klimatu zaufania powinni rozwijać relacje oparte na prawdzie i wartościach oraz konsekwentnie komunikować dobrą wolę wobec pracowników, polegającą na stworzeniu w organizacji atmosfery wiary w to, że menedżer chce dla pracowników i firmy jak najlepiej (Burton, 2006, s. 32-36). Kiedy pracownicy ufają, że przełożony nie wyko- 
rzysta swojej pozycji do działań niezgodnych z ich interesem i nie nadużyje ich praw, są bardziej skłonni do współpracy, wypełniania poleceń kierownika i kreatywnego zaangażowania się w funkcjonowanie przedsiębiorstwa. Są także w stanie osiągnąć większe zadowolenie z wykonywanej pracy (Robbins, 1998, s. 272).

Proces wzbudzania zaufania jest długotrwały i rozłożony w czasie, a składają się na niego takie elementy (cechy przełożonego), jak (Mayer, Davis, Schoorman, 1995, s. 717-720):

- kompetencje,

- uczciwość,

- życzliwość,

- otwartość,

- sprawiedliwość,

- wyrażanie swoich uczuć,

- mówienie prawdy,

- konsekwencja,

- szanowanie zwierzeń,

- wykazywanie się pewnością siebie.

Kompetencje to kwalifikacje i umiejętności posiadane przez kierownika. Uczciwość jest rozumiana jako zdolność do dotrzymywania danego podwładnym słowa i spełniania obietnic. Życzliwość oznacza skłonność do działania w dobrej wierze i z uwzględnieniem interesów pracownika, niezależnie od sytuacji. Otwarte informowanie o problemach, odczuciach, sposobie podejmowania decyzji jest podstawą zaufania. Przy podejmowaniu wszelkich ocen danych sytuacji należy kierować się obiektywnością i bezstronnością, zapewniając sprawiedliwy osąd. Ufa się wyłącznie osobie prawdomównej (nawet jeśli usłyszana prawda jest niewygodna) oraz konsekwentnie kierującej się głoszonymi wartościami. Równie ważnym czynnikiem jest dyskrecja. Należy pamiętać o zasobach wiedzy, która daje pewność siebie w planowanych działaniach, a następnie ich realizacji (Robbins, Delenzo, 2002, s. 498).

Kierownicy, którzy mają większe zaufanie do swoich pracowników, częściej wysyłają ich na szkolenia i inwestują w nich (Tzafrir, Eitam-Meilik, 2005, s. 193-207). Z kolei wyższy poziom inwestycji w szkolenia wzmacnia i podtrzymuje zaufanie do organizacji (Reade, 2003, s. 9). Kiedy przełożeni troszczą się o swoich podwładnych, pomagają im w rozwoju, w karierze i doceniają ich pracę, pracownicy czują się wtedy wyróżnieni i dowartościowani, co obliguje ich do wydajniejszej pracy (Paliszkiewicz, 2013, s. 83). Zaangażowanie pracowników przyczynia się do wzrostu produktywności, zmniejsza fluktuację i absencję (Garg, Rastogi, 2009, s. 42-51), 
dlatego należy unikać działań (błędów), które zmniejszają zaufanie. Należą do nich (Shockley-Zalabak, Morreale, Hackman, 2010, s. 202):

- błędy w strategii i niejasna wizja,

- zwolnienia pracowników,

- brak komunikacji i ukrywanie informacji,

- niskie wynagrodzenia.

Oprócz powyższych można jeszcze podać kilka kolejnych przykładów, takich jak: niekonsekwentność kierownictwa, tolerowanie niekompetencji i złych zachowań, zdrada, uprzedzenia, podejrzliwość, stronniczość, strach, a także różne przejawy oszustwa, łącznie z kłamstwem.

Jeżeli ludzie nie ufają przywódcy lub menedżerowi, to zespół nie osiągnie długoterminowego sukcesu. Zaufanie jest kluczem do motywowania ludzi, mobilizowania ich do pracy i osiągania wspólnych celów.

\section{Założenia metodyczne badań własnych}

Podstawowym celem badania było uzyskanie informacji na temat postrzegania badanej organizacji przez jej pracowników pod kątem zaufania i reputacji. Badanie zostało przeprowadzone w grudniu 2014 roku w jednej z polskich publicznych uczelni wyższych. W badaniach wykorzystano kwestionariusz ankiety internetowej (Rószkiewicz, Perek-Białas, Węziak-Białowolska, Zięba-Pietrzak, 2013, s. 134-135). Link do ankiety zamieszczonej na jednym z portali badawczych został wysłany pocztą elektroniczną do wszystkich pracowników naukowo-dydaktycznych zatrudnionych na dwóch wydziałach, z których jeden reprezentował nauki społeczne, a drugi nauki techniczne. Na każdym wydziale było zatrudnionych ponad 100 pracowników. Badania były całkowicie anonimowe. Ostatecznie w badaniu wzięło udział 97 respondentów (wypełnionych ankiet). Wskaźnik odpowiedzi osiągnięto na poziomie około 40\%. Przeważającą liczbę respondentów stanowili mężczyźni - 64\%. Pod względem wieku najliczniejszą grupą byli pracownicy w przedziale wiekowym 41-50 lat (37\%) oraz 30-40 lat (31\%). Najmniej liczną grupą pracowników były osoby w wieku poniżej 30 lat (8\%). Pracownicy biorący udział w badaniu to najczęściej osoby z ponad 10-letnim stażem (67\% respondentów). Osoby ze stażem pracy nieprzekraczającym 4 lat stanowiły 11\% respondentów. Przeważająca liczba ankietowanych pracowników posiadała stopień naukowy doktora $-60 \%$ (tabela 1). 
Badani z tytułem magistra stanowili $22 \%$ badanych. Pracownicy ze stopniem naukowym doktora habilitowanego stanowili 13\% próby. Najmniej liczną grupą pracowników były osoby z tytułem profesora (5\%).

Tabela 1. Struktura badanej próby

\begin{tabular}{|l|l|c|}
\hline \multicolumn{1}{|c|}{$\begin{array}{c}\text { Kryterium } \\
\text { podziału }\end{array}$} & \multicolumn{1}{|c|}{ Struktura } & Udział \\
\hline Płeć & kobieta & $36 \%$ \\
& mężczyzna & $64 \%$ \\
\hline \multirow{5}{*}{ Wiek } & poniżej 30 lat & $8 \%$ \\
& 30-40 lat & $31 \%$ \\
& 41-50 lat & $37 \%$ \\
& 51-60 lat & $13 \%$ \\
& powyżej 60 lat & $10 \%$ \\
\hline \multirow{5}{*}{ Staż pracy } & poniżej 5 lat & $11 \%$ \\
& 5-10 lat & $22 \%$ \\
& 11-20 lat & $38 \%$ \\
Tytuł zawodowy & powyżej 20 lat & $29 \%$ \\
lub stopień/ & magister & $22 \%$ \\
tytuł naukowy & doktor & $60 \%$ \\
& doktor habilitowany & $13 \%$ \\
profesor & $5 \%$ \\
\hline
\end{tabular}

Źródło: opracowanie własne.

\section{Wyniki badań własnych}

Ankietowani pracownicy określali swój poziom zaufania do uczelni przez ocenę 20 czynników w skali od 1 do 10 punktów, gdzie 1 oznaczało „całkowicie nie zgadzam się z danym stwierdzeniem”, zaś 10 - „całkowicie się zgadzam”. Z danych zawartych w tabeli 2 wynika, że poszczególne kryteria określające zaufanie zostały ocenione od 4,01 pkt do 8,72 pkt. Średni poziom zaufania organizacyjnego w badanej instytucji wynosił 5,82 pkt. Taki wynik pozwala stwierdzić, że zaufanie pracowników do pracodawcy nie jest najmocniejszą stroną uczelni. Analizując dokładniej otrzymane wyniki, badane kryteria zaufania można podzielić na trzy umowne grupy. W pierwszej grupie znalazły się czynniki ocenione najgorzej, to znaczy $\mathrm{z}$ oceną poniżej $5 \mathrm{pkt}$. Takim przykładem jest niesprawiedliwa ocena pracowników oraz niechęć personelu do otwartego przyznania się do popełnionych błędów. Należy jeszcze zauważyć niezadowolenie z polityki płacowej, niskiego poziomu inwestycji 
w szkolenia i rozwój oraz niechęć pracowników do dzielenia się wiedzą. Na uwagę zasługuje również nisko oceniona polityka równych szans i możliwości.

Druga grupa to czynniki ocenione od 5 do 6,5 pkt. Są to oceny niezbyt wysokie, jednak w sposób naturalny wyższe od uzyskanych w poprzedniej grupie. Zidentyfikowano 10 elementów, które odnoszą się m.in. do komunikacji kierownictwa z pracownikami, wykorzystania wiedzy i doświadczenia pracowników, znajomości celów i kierunków rozwoju uczelni, precyzyjności informacji i komunikatów przełożonych. Pracownicy uważają również, że w pracy panuje miła atmosfera $(6,39)$.

Tabela 2. Poziom zaufania wewnątrzorganizacyjnego w badanej uczelni

\begin{tabular}{|c|c|}
\hline Kryterium & Ocena \\
\hline Wizerunek wewnętrzny organizacji & 6,35 \\
\hline Jestem dumny, że jestem częścią uczelni & 7,38 \\
\hline Czuję, że moje stanowisko jest stabilne & 5,31 \\
\hline Znajomość misji, wizji i celów organizacji & 6,2 \\
\hline Znam cele i kierunki rozwoju uczelni & 5,94 \\
\hline Znam misję uczelni & 6,44 \\
\hline Kompetencje i postawa kierownictwa & $\mathbf{5 , 5 7}$ \\
\hline Kierownictwo uczelni komunikuje się z pracownikami & 5,13 \\
\hline Informacje i komunikaty przełożonych są precyzyjne & 5,97 \\
\hline Uczelnia wykorzystuje wiedzę i doświadczenie pracowników & 5,26 \\
\hline Czuję wsparcie przełożonych & 5,93 \\
\hline Kompetencje i postawa pracowników & 6,5 \\
\hline Jestem kompetentnym pracownikiem & 8,32 \\
\hline Jestem zaangażowanym pracownikiem & 8,72 \\
\hline Pracownicy uczelni chętnie dzielą się swoją wiedzą ze współpracownikami & 4,95 \\
\hline Pracownicy uczelni otwarcie przyznają się do błędów, jeśli je popełnili & 4,01 \\
\hline Atmosfera pracy & 5,89 \\
\hline W pracy panuje miła atmosfera & 6,39 \\
\hline Na uczelni nie występuje zjawisko mobbingu & 5,76 \\
\hline Zawsze otwarcie mówię to, co myślę & 7,29 \\
\hline Ocena pracowników uczelni jest sprawiedliwa & 4,3 \\
\hline Kryteria oceny pracowników uczelni są precyzyjne i jasno określone & 5,7 \\
\hline Polityka płacowa oraz możliwości rozwoju i awansu & 4,55 \\
\hline Jestem zadowolony z polityki płacowej uczelni & 4,52 \\
\hline Na uczelni panuje polityka równych szans i możliwości & 4,55 \\
\hline Uczelnia jest zaangażowana w szkolenia i rozwój pracownika & 4,59 \\
\hline $\begin{array}{l}\text { Średnia ocena } \\
\end{array}$ & 5,82 \\
\hline
\end{tabular}

Źródło: badania własne. 
Trzecia grupa czynników dotyczyła elementów ocenionych powyżej 7 pkt. Według badanych elementy zaufania, którymi uczelnia wyróżnia się pozytywnie, to zaangażowanie i kompetencje pracowników. Są oni dumni, że stanowią część uczelni wyższej. Twierdzą również, że są otwarci i zawsze mówią to, co myślą.

Tabela 3. Poziom zaufania wewnątrzorganizacyjnego w badanej uczelni ze względu na tytuł/stopień naukowy/zawodowy pracowników

\begin{tabular}{|c|c|c|c|c|}
\hline \multirow[b]{2}{*}{ Kryterium } & \multicolumn{4}{|c|}{ Ocena } \\
\hline & magister & doktor & $\begin{array}{l}\text { doktor } \\
\text { hab. }\end{array}$ & profesor \\
\hline Wizerunek wewnętrzny organizacji & 6,1 & 6,05 & 7 & 9,1 \\
\hline Jestem dumny, że jestem częścią uczelni & 7,14 & 7,36 & 7,31 & 8,8 \\
\hline Czuję, że moje stanowisko jest stabilne & 5,05 & 4,74 & 6,69 & 9,4 \\
\hline Znajomość misji, wizji i celów organizacji & 5,93 & 5,77 & 7,19 & 9,6 \\
\hline Znam cele i kierunki rozwoju uczelni & 5,67 & 5,5 & 6,92 & 9,6 \\
\hline Znam misję uczelni & 6,19 & 6,03 & 7,46 & 9,6 \\
\hline Kompetencje i postawa kierownictwa & 6,02 & 5,23 & 5,62 & 7,55 \\
\hline Kierownictwo uczelni komunikuje się z pracownikami & 5 & 4,78 & 6,15 & 7,2 \\
\hline Informacje i komunikaty przełożonych są precyzyjne & 6,43 & 5,74 & 5,46 & 8 \\
\hline Uczelnia wykorzystuje wiedzę i doświadczenie pracowników & 5,95 & 4,97 & 4,85 & 6,8 \\
\hline Czuję wsparcie przełożonych & 6,71 & 5,43 & 6 & 8,2 \\
\hline Kompetencje i postawa pracowników & 6,64 & 6,36 & 6,44 & 7,7 \\
\hline Jestem kompetentnym pracownikiem & 7,95 & 8,36 & 8,46 & 9 \\
\hline Jestem zaangażowanym pracownikiem & 8,33 & 8,74 & 9 & 9,4 \\
\hline $\begin{array}{l}\text { Pracownicy uczelni chętnie dzielą się swoją wiedzą ze } \\
\text { współpracownikami }\end{array}$ & 5,81 & 4,53 & 4,62 & 7 \\
\hline Pracownicy uczelni otwarcie przyznają się do błędów, jeśli je popełnili & 4,48 & 3,79 & 3,69 & 5,4 \\
\hline Atmosfera pracy & 6,21 & 5,71 & 5,84 & 6,8 \\
\hline W pracy panuje miła atmosfera & 7,43 & 6,14 & 5,15 & 8,2 \\
\hline Na uczelni nie występuje zjawisko mobbingu & 6,14 & 5,59 & 6,69 & 3,8 \\
\hline Zawsze otwarcie mówię to, co myślę & 7,19 & 7 & 8,15 & 8,8 \\
\hline Ocena pracowników uczelni jest sprawiedliwa & 4,71 & 4,02 & 4,23 & 6 \\
\hline Kryteria oceny pracowników uczelni są precyzyjne i jasno określone & 5,57 & 5,78 & 5 & 7 \\
\hline Polityka płacowa oraz możliwości rozwoju i awansu & 4,6 & 4,32 & 4,64 & 6,73 \\
\hline Jestem zadowolony z polityki płacowej uczelni & 4,71 & 4,31 & 4,23 & 6,8 \\
\hline Na uczelni panuje polityka równych szans i możliwości & 4,67 & 4,26 & 4,85 & 6,6 \\
\hline Uczelnia jest zaangażowana w szkolenia i rozwój pracownika & 4,43 & 4,4 & 4,85 & 6,8 \\
\hline Średnia ocena & 5,98 & 5,57 & 5,99 & 7,63 \\
\hline
\end{tabular}


Grupując pojedyncze kryteria w zbiorcze wymiary, można zauważyć, że badany podmiot ma największe problemy z polityką płacową i możliwościami rozwoju kadry naukowo-dydaktycznej. Stąd prawdopodobnie niska ocena atmosfery pracy i kompetencji kierownictwa (poniżej 6 pkt). Nieco lepiej pracownicy ocenili swoje kompetencje i wizerunek organizacji (powyżej 6 pkt). Są to wyniki, które zdaniem autora, zmuszają do przemyśleń i większych wysiłków na rzecz budowy zaufania wewnątrz organizacji.

Następnym etapem analizy było porównanie zaufania pracowników w zależności od zajmowanego stanowiska (związanego głównie z posiadanym tytułem/ stopniem naukowym). Osoby z tytułem profesora charakteryzują się najwyższym poziomem zaufania do organizacji na tle pozostałych grup pracowników (tabela 3). W grupie osób z tytułem profesora najwyżej ocenione elementy zaufania to znajomość celów i kierunków rozwoju uczelni (9,60pkt), znajomość misji (9,60pkt), stabilność stanowiska (9,40 pkt), zaangażowanie pracowników (9,40pkt).

Najbardziej krytyczną grupą pracowników uczelni były osoby ze stopniem doktora. Warto zwrócić uwagę na fakt, że osoby te 9 czynników na 20 poddanych badaniu oceniły poniżej 5 pkt na 10 -stopniowej skali. Pracownicy ze stopniem doktora to osoby zaangażowane oraz kompetentne, pracujące w miłej atmosferze. Jednakże uważają, że ocena ich pracy jest niesprawiedliwa. Nie mają również zapewnionych równych szans i możliwości rozwoju.

Kryteria zaufania, które zostały najwyżej ocenione w grupie osób z tytułem magistra, to zaangażowanie pracowników $(8,33 \mathrm{pkt})$ oraz kompetencje $(7,95 \mathrm{pkt})$. Nieco niżej ocenili oni miłą atmosferę w pracy (7,43 pkt), otwartą komunikację (7,19 pkt) oraz dumę z faktu, że są częścią danej uczelni (7,14 pkt). Natomiast najniżej ocenione elementy przez osoby z tytułem magistra to inwestycja w szkolenia i rozwój (4,43 pkt), otwartość przyznawania się do błędów (4,48 pkt) oraz polityka równych szans i możliwości $(4,67 \mathrm{pkt})$. Osoby z tytułem magistra nie są także usatysfakcjonowani ze swojej płacy $-4,71$ pkt.

W grupie osób ze stopniem doktora habilitowanego najwyżej ocenione kryteria to zaangażowanie pracowników ( 9 pkt), kompetencje (8,46 pkt) oraz otwarta komunikacja $(8,15$ pkt). Natomiast najniżej grupa osób ze stopniem doktora habilitowanego oceniła otwartość przyznawania się do błędów (3,69 pkt), sprawiedliwość oceny pracowników, zadowolenie ze swojego wynagrodzenia. 


\section{Podsumowanie}

Brak zaufania w organizacji lub do organizacji to brak odpowiedzialności społecznej. Skutki braku zaufania prowadzą do niskiej jakości produktów i usług, obniżają zadowolenie klienta i pracownika oraz zyski, ograniczając perspektywy rozwoju każdej firmy. Zaufanie potrzebuje silnego przywództwa, zaangażowania, otwartej komunikacji i szczerych zachowań opartych na mocnych etycznych podstawach. Jeżeli ludzie nie ufają sobie, to nie osiągną sukcesu. Zaufanie jest kluczem do motywowania ludzi, mobilizowania ich do pracy i osiągania wspólnych celów. Wiarygodność organizacji stanowi fundament lojalności, co gwarantuje osiągnięcie ponadprzeciętnych korzyści ekonomicznych.

Pomiar zaufania organizacyjnego przedstawiono na przykładzie uczelni. Niestety badani nauczyciele akademiccy nie odczuwali satysfakcji w swojej pracy, a zaufanie pracowników nie było mocną stroną uczelni. W organizacji zauważono negatywne zjawiska, które nie sprzyjają zaufaniu.

\section{Literatura}

Anderson, J.A. (2005). Trust in managers: a study of why Swedish subordinates trust their managers. Business Ethics. A European Review, 14 (4).

Andrzejczyk, C. (2015). Zarzadzanie reputacja w branży finansowej. Pobrane z: http://www. proto.pl/PR/Pdf/zarzadzanie_reputacja_organizacji.pdf (dostęp 10.11.2015).

Burton, S.K. (2006). Without trust. You have nobody. Effective Employee communications for today and Tomorrow. Public Relations Strategist, 12 (2).

Garg, P., Rastogi, R. (2009). Effect of psychological wellbeing on organizational commitment of employee. Journal of Organizational Behavior, 8 (2).

Kiyosaki, R.T., Lechter, S.L. (2006). Szkoła biznesu dla ludzi, którzy lubia pomagać innym. Osielsko: Instytut Praktycznej Edukacji.

Levin, D.Z., Cross, R., Abrams, L.C., Lesser, E.L. (2002). Trust and knowledge sharing: A critical combination. IBM Institute for Knowledge - Based Organizations. Pobrane z: http://www-935.ibm.com/services/in/igs/pdf/g510-1693-00-cpov-trust-and-knowledge-sharing.pdf.

Mayer, R.C., Davis, J.H., Schoorman, F.D. (1995). An integrative model of organizational trust. Academy of Management Review, 20.

Paliszkiewicz, J. (2013). Zaufanie w zarzadzaniu. Warszawa: Wydawnictwo Naukowe PWN. Reade, Q. (2003). Top-level training helps Cola Giant rebuild trust and cut staff turnover. Personnel Today, 5 (27).

Robbins, S.P. (1998). Zachowania w organizacji. Warszawa: PWE. 
Robbins, S.P., Delenzo, D.A. (2002). Podstawy zarzadzania. Warszawa: PWE.

Rószkiewicz, M., Perek-Białas, J., Węziak-Białowolska, D., Zięba-Pietrzak, A. (2013). Projektowanie badań społeczno-ekonomicznych. Rekomendacje i praktyka badawcza. Warszawa: Wydawnictwo Naukowe PWN.

Shockley-Zalabak, P.S., Morreale, S.P., Hackman, M.Z. (2010). Building the high-trust organization. San Francisco: Jossey-Bass.

Tzafrir, S.S., Eitam-Meilik, M. (2005). The impact of downsizing on trust and employee practices in high tech firms. A longitudinal analysis. Journal of High Technology Management Research, 16.

\title{
MEASUREMENT OF TRUST INTERNAL ORGANIZATION
}

\begin{abstract}
The purpose of this article is to identify the role of the workers' trust in the functioning of modern organizations and to attempt direct measurement of organizational trust. Trust is the key to motivating people, mobilizing them to work and achieve common goals. If people do not trust each other, they will not achieve success. The organization's credibility is the foundation of employee loyalty. Trust needs strong leadership, commitment, open communication and honest behavior based on strong ethical principles. Despite the great importance of trust in the organization, in practice this is a topic ignored. The study in the university suggest the presence of negative phenomena. Employees feel a low degree of satisfaction. Trust of employees to employers is not the strongest point of tested university.
\end{abstract}

Translated by Adam Rudzewicz

Keywords: trust, organization, image, personnel

JEL Codes: M14, M54 